\title{
Effects of Procyanidin on Meat Quality and Shelf-Life for Preserving Pork Patties during Chilled Storage
}

\author{
Jin Young Jeong ${ }^{\dagger}$, Kuk-Hwan Seol ${ }^{\dagger}$, Pil-Nam Seong, Beom-Young Park, and Hyoun Wook Kim* \\ Animal Products Utilization Division, National Institute of Animal Science, RDA, Wanju 565-851, Korea
}

\begin{abstract}
Grape seeds and pericarp are rich in procyanidins, a class of natural antioxidants and antimicrobials that can provide phytonutrients for healthy eating and extend food shelf life. The objective of this study was to assess the effect of procyanidins as preservatives in pork meat patties for $14 \mathrm{~d}$. Pork patties were treated with $0,0.1$, or $0.3 \%$ procyanidin, and meat color, $\mathrm{pH}$, volatile basic nitrogen (VBN), $2-$ thiobarbituric acid reactive substance (TBARS) values, and microbial populations were determined during storage at $4{ }^{\circ} \mathrm{C}$ for $14 \mathrm{~d}$. The color of pork patties treated with procyanidin showed lower lightness and higher redness values than untreated controls, and procyanidin treatment reduced $\mathrm{pH}$ values significantly $(p<0.05)$. VBN values decreased significantly $(p<0.05)$ with the $0.3 \%$ procyanidin treatment and increased significantly $(p<0.05)$ during storage. TBARS values were markedly lower in procyanidin-treated meat than in the untreated control. In addition, procyanidin suppressed total bacterial colony and Escherichia coli counts significantly $(p<0.05)$ relative to the control samples. Our findings suggest that procyanidin could be used as a food preservative in pork patties due to its natural antioxidation and antimicrobial activities, and that it may contribute to an improved healthy diet.
\end{abstract}

Keywords: procyanidin, pork patties, antioxidant, antimicrobial

Received April 30; 2015, July 29, 2015; Accepted July 29, 2015

\section{Introduction}

The shelf life of meat products is shortened by microbial contamination resulting from manufacturing processes or storage conditions, and suitable meat product preservatives are thus required to prevent contamination by various pathogenic microbes that cause food-borne diseases in humans. Lipid oxidation and microbiological spoilage cause deterioration in quality and diminished nutritional value of meat products accompanied by alterations in meat color and flavor components (Ahn et al., 2007; Dave and Ghaly, 2011). Many additives have been used for centuries to preserve flavor and improve the taste or shelf life of meats, and recently, new natural and artificial additives have been identified as preservatives to prevent or inhibit food spoilage via their antioxidant or antimicrobial activities (Barbosa-Pereira et al., 2015; Mit-

\footnotetext{
${ }^{\dagger}$ These two authors contribute equally to this work.

*Corresponding author: Hyoun Wook Kim. Animal Products Utilization Division, National Institute of Animal Science, Rural Development Administration, Wanju 565-851, Korea. Tel: +8263-238-7376, Fax: +82-63-238-7397, E-mail: woogi78@korea. $\mathrm{kr}$
}

ropoulou et al., 2015).

Antioxidants activities are exhibited by several vitamins, such as vitamin $\mathrm{C}, \mathrm{E}$, and the vitamin A precursor $\beta$-carotene, by some spices including rosemary and oregano, and by grapes (Hemilä et al., 2006; Rojas and Brewer, 2007; Sasse et al., 2009). Moreover, the by-product or extract of grapes as antioxidant has been used in fish oil and frozen fish (Pazos et al., 2005), pork patties (Nissen et al., 2004), and cooked turkey (Loizzo et al., 2015; Sivarooban et al., 2007), and green tea has also been used to increase the shelf life of meat patties (Bañón et al., 2007; Jo et al., 2003; Shah et al., 2014). The antioxidant activity of these sources exhibit efficacy similar to that of synthetic antioxidants such as butylated hydroxyanisole (BHA) and butylated hydroxytoluene (BHT), but less than that of rosemary extract (Karre et al., 2013; Movileanu et al., 2013). Synthetic antioxidants are used to inhibit lipid oxidation, but recently, natural antioxidants are receiving greater attention from consumers due to increasing concerns of human health and/or biology effects.

Grapes are of special interest as a source of antioxidants due to their high content of phenolic compounds. Grape seeds are especially rich in phenolic compounds such as catechin, epicatechin, and dimeric, trimeric, and

(9)This is an open access article distributed under the terms of the Creative Commons Attribution Non-Commercial License (http://creativecommons.org/licences/ by-nc/4.0) which permits unrestricted non-commercial use, distribution, and reproduction in any medium, provided the original work is properly cited. 
tetrameric procyanidins (Negro et al., 2003), although monomeric procyanidins in grape seed extract are not able to inhibit lipid hydroperoxide or propanal formation $(\mathrm{Hu}$ et al., 2004). In particular, procyanidin is an excellent, wellknown antioxidant that is more effective than either vitamin $\mathrm{C}$ or $\mathrm{E}$, and the polyphenolic procyanidin compounds in grapes are contained in both the seed and the pericarp (Shi et al., 2003; Wood et al., 2002). However, both seed and the pericarp are discarded after being processed.

Procyanidins are a family of proanthocyanidin compounds called flavonoids, which in oligomeric form have antioxidant properties. Some studies of procyanidin content and structure in foods have addressed the relevance of the antioxidant properties and potential effects of procyanidin additives on pork patties, but their effects have not been well established. Thus, the objective of this study was to investigate the effect of procyanidin on pork patty shelf life during various storage periods.

\section{Materials and Methods}

\section{Determination of experimental procyanidin concen- trations}

Procyanidin was obtained from Konkuk University, South Korea, as a brown powder of purity $97 \%(\mathrm{w} / \mathrm{v})$. Procyanidins were extracted according to GMP standard from grape seeds. Powder is supplied with vacuum bags. Procyanidin concentrations were determined based on 2,2'azino-bis-(3-ethylbenzothiazoline-6-sulfoni acid) (ABTS) radical scavenging activity. ABTS activity was determined for pork patties treated with procyanidin at concentrations of $0,0.1,0.3,1$, or $5 \%$. Preliminary experiments showed that high procyanidin concentrations altered the thiobarbituric acid reactive substances (TBARS) values and color of the meat patties, and we treated pork patties with procyanidin concentrations of 0.1 and $0.3 \%$ in subsequent experiments, because ABTS radical scavenging activities of 1 and $5 \%$ were similar to $0.3 \%$ procyanidin.

\section{Preparation of pork patties}

A fresh pork loin obtained from a local meat market and immediately processed it to form pork patties. The meat was trimmed to remove the excess fat and connective tissue, and minced twice using a meat mincer (Model 7548, Biro MFG, Co., USA). The minced meat was mixed with procyanidin at concentrations of 0.1 and $0.3 \%$ and then formed into patties (100 g portions; $10 \mathrm{~cm}$ in diameter and $1.5 \mathrm{~cm}$ thick). The formed patties were heated in $80^{\circ} \mathrm{C}$ water bath for $30 \mathrm{~min}$ and then cooled at $4 \pm 1^{\circ} \mathrm{C}$ for
30 min to remove excess moisture. All patties were packaged in low-density polyethylene (LDPE) bags $(25 \mu \mathrm{m}$ thickness) with oxygen permeability and a water vapor transmission rate to protect against microbe at $4^{\circ} \mathrm{C}$ for 14 d. We measured the color, $\mathrm{pH}$, volatile basic nitrogen (VBN), and TBARS values and microbial populations with the pork patties for $0,1,3,7,10$, and $14 \mathrm{~d}$.

\section{Color measurement}

Patty color parameters including lightness $\left(\mathrm{L}^{*}\right)$, redness $\left(a^{*}\right)$, and yellowness $\left(b^{*}\right)$ were determined using a Minolta Color Reader (CR-400; Minolta, Japan). Before use, the colorimeter was standardized $\left(\mathrm{L}^{*}=86.3, \mathrm{a}^{*}=0.3165\right.$, and $b^{*}=0.3142$ ) using a calibration plate. Color was measured on the surface of the pork patties after opening the LDPE bags. Color determinations were taken in quadruplicate in different areas of the sample surface. The results were expressed as lightness $\left(\mathrm{L}^{*}\right)$, redness $\left(\mathrm{a}^{*}\right)$, and yellowness $\left(\mathrm{b}^{*}\right)$.

\section{pH determination}

Portions $(5 \mathrm{~g})$ of the pork patties were dissolved in 45 $\mathrm{mL}$ of distilled water and homogenized using a PT-MR 2100 homogenizer (Kinematica, Switzerland). A digital Orion 3-Star Plus pH meter (Thermo Scientific, USA) with a glass probe was used to measure $\mathrm{pH}$ values, which were determined for all experimental periods.

\section{Measurement of $\mathrm{VBN}$ content}

The VBN content as an indicator of meat freshness was measured in this study. VBN was determined using the Conway microdiffusion method (Conway, 1950). A meat sample ( $5 \mathrm{~g}$ ) was mixed with $45 \mathrm{~mL}$ of distilled water and homogenized at 14,000 rpm for $1 \mathrm{~min}$. The homogenate was filtered through no. 1 filter paper (Whatman, UK). The filtrate $(1 \mathrm{~mL})$ was transferred to the outer chamber of a Conway microdiffusion unit, and $1 \mathrm{~mL}$ of $0.01 \mathrm{~N}$ boric acid $\left(\mathrm{H}_{3} \mathrm{BO}_{3}\right)$ and $50 \mu \mathrm{L}$ of Conway reagent $(0.066 \%$ methyl red:0.066\% bromocresol green, 1:1) as an indicator were added to the inner chamber of the device. The Conway unit was sealed immediately after the addition of $1 \mathrm{~mL}$ of $50 \%$ potassium carbonate $\left(\mathrm{K}_{2} \mathrm{CO}_{3}\right)$ to the outer chamber, and the materials were incubated at $37^{\circ} \mathrm{C}$. The VBN contents were determined following the addition of $0.02 \mathrm{~N}$ sulfuric acid $\left(\mathrm{H}_{2} \mathrm{SO}_{4}\right)$ to the inner chamber of the Conway unit.

\section{Determination of TBARS values}

The lipid peroxidation (i.e., lipid degradation) was monitored in pork patties using a TBARS assay. TBARS 
values were measured as described previously (Witte et al., 1970). Meat samples (10 g) were added to $35 \mathrm{~mL}$ of $2 \mathrm{M}$ phosphate buffer (pH 7.2) [20\% trichloroacetic acid (TCA)] and $50 \mathrm{~mL}$ of $7.2 \%$ butylated hydroxytoluene (BHT) and homogenized at 14,000 rpm for $1 \mathrm{~min}$ followed by filtration through Whatman no.1 filter paper. Filtered samples $(5 \mathrm{~mL})$ were mixed with $5 \mathrm{~mL}$ of $0.005 \mathrm{M} \mathrm{2-}$ thiobarbituric acid (TBA) and incubated for $15 \mathrm{~h}$ in darkness. The absorbance of the mixture was measured at 530 nm (A530) using a double beam SpectraMax Plus 384 UV-VIS Spectrophotometer (Molecular Devices, USA). The results were expressed as $\mathrm{mg}$ of malonaldehyde $/ \mathrm{kg}$ of the patty sample and calculated by multiplying the absorbance at $532 \mathrm{~nm}$.

\section{Microbiological analysis}

Microbial analysis was performed using 3M Petrifilm (3M Health Care, USA). Patty samples ( $25 \mathrm{~g}$ ) were homogenized or blended with $225 \mathrm{~mL}$ of sterile distilled water, and the samples were diluted serially tenfold. Subsequently, $1 \mathrm{~mL}$ of each diluted sample was spread on Petrifilm Aerobic Count Plates (3M Health Care) to determine the total bacterial counts (TBCs), and the plates were incubated at $37 \pm 1{ }^{\circ} \mathrm{C}$ for $24-48$ h. Escherichia coli was incubated on Petrifilm E. coli/Coliform Count Plates (3M Health Care) for 24-36 h under identical conditions. After incubation, the colonies were counted and transformed as $\log _{10}$ colony forming units (CFU)/g of sample after 0,1 , $3,7,10$, and $14 \mathrm{~d}$ of storage.

\section{Statistical analysis}

The data are expressed as means \pm standard deviation (SD). Differences among mean values determined for different storage periods or treatments were evaluated using a Tukey's multiple comparison of the SAS software (SAS Institute, USA). $p<0.05$ was considered to reflect statistical significance. All experiments were performed in triplicate or quadruplicate with replicates in each experiment.

\section{Results and Discussion}

\section{Color evaluation}

The effect of procyanidin on the color of pork patties was evaluated for various storage periods (Table 1 ). $\mathrm{L}^{*}$ values were not significantly different at storage periods and procyanidin treatments. Generally, $\mathrm{L}^{*}$ values were lower $(p<0.05)$ after $14 \mathrm{~d}$ of storage for the procyanidintreated samples than for the initial control. This finding was similar to those of previous studies. The particulate metmyoglobin was associated with color parameters in beef patties (Bekhit et al., 2003). Tea catechins treatment had an effect on $\mathrm{L}^{*}$ values in meat patties (Mitsumoto et

Table 1. Effect of procyanidin on the color values of pork patties during storage periods

\begin{tabular}{|c|c|c|c|c|}
\hline \multirow{2}{*}{ Parameters } & \multirow{2}{*}{ Storage time (d) } & \multicolumn{3}{|c|}{ Procyanidin (\%) } \\
\hline & & 0 & 0.1 & 0.3 \\
\hline \multirow{6}{*}{$\mathrm{L}^{*}$} & 0 & $69.70 \pm 1.82^{\mathrm{abA}}$ & $66.07 \pm 1.21^{\mathrm{abB}}$ & $66.39 \pm 1.57^{\mathrm{abB}}$ \\
\hline & 1 & $70.39 \pm 1.63^{\mathrm{abA}}$ & $66.01 \pm 1.18^{\mathrm{abB}}$ & $66.88 \pm 1.26^{\mathrm{aB}}$ \\
\hline & 3 & $69.94 \pm 1.63^{\mathrm{abA}}$ & $66.44 \pm 1.76^{\mathrm{abB}}$ & $64.95 \pm 0.92^{\mathrm{cC}}$ \\
\hline & 7 & $70.96 \pm 2.19^{\mathrm{aA}}$ & $66.80 \pm 1.27^{\mathrm{aB}}$ & $66.08 \pm 0.99^{\mathrm{abB}}$ \\
\hline & 10 & $68.88 \pm 2.03^{\mathrm{bA}}$ & $65.39 \pm 0.83^{\mathrm{bB}}$ & $64.43 \pm 1.57^{\mathrm{cB}}$ \\
\hline & 14 & $70.24 \pm 1.25^{\mathrm{abA}}$ & $66.90 \pm 1.63^{\mathrm{aB}}$ & $65.46 \pm 0.80^{\mathrm{bcC}}$ \\
\hline \multirow{6}{*}{$a^{*}$} & 0 & $5.31 \pm 0.93^{\mathrm{A}}$ & $5.45 \pm 0.39^{\mathrm{bA}}$ & $5.86 \pm 0.69^{\mathrm{cA}}$ \\
\hline & 1 & $4.91 \pm 1.43^{\mathrm{A}}$ & $5.67 \pm 0.49^{\mathrm{bA}}$ & $5.69 \pm 1.01^{\mathrm{dA}}$ \\
\hline & 3 & $5.23 \pm 0.81^{\mathrm{B}}$ & $5.73 \pm 0.40^{\mathrm{bAB}}$ & $6.01 \pm 0.54^{\mathrm{cdA}}$ \\
\hline & 7 & $4.97 \pm 0.87^{\mathrm{C}}$ & $5.77 \pm 0.49^{\mathrm{bB}}$ & $6.54 \pm 1.22^{\mathrm{cbA}}$ \\
\hline & 10 & $5.86 \pm 1.03^{\mathrm{B}}$ & $7.21 \pm 1.35^{\mathrm{aA}}$ & $7.36 \pm 0.56^{\mathrm{aA}}$ \\
\hline & 14 & $5.44 \pm 1.12^{\mathrm{B}}$ & $5.90 \pm 0.92^{\mathrm{bB}}$ & $6.97 \pm 0.65^{\mathrm{abA}}$ \\
\hline \multirow{6}{*}{$b^{*}$} & 0 & $11.74 \pm 0.73^{\mathrm{aB}}$ & $11.24 \pm 0.47^{\mathrm{aC}}$ & $12.28 \pm 0.46^{\mathrm{abA}}$ \\
\hline & 1 & $11.80 \pm 0.64^{\mathrm{aB}}$ & $11.23 \pm 0.49^{\mathrm{aC}}$ & $12.57 \pm 0.45^{\mathrm{aA}}$ \\
\hline & 3 & $11.44 \pm 0.74^{\mathrm{aB}}$ & $10.87 \pm 0.56^{\mathrm{abC}}$ & $12.12 \pm 0.32^{\mathrm{bcA}}$ \\
\hline & 7 & $12.07 \pm 0.70^{\mathrm{aA}}$ & $10.40 \pm 0.80^{\mathrm{bcC}}$ & $11.29 \pm 0.43^{\mathrm{dB}}$ \\
\hline & 10 & $10.14 \pm 3.12^{\mathrm{bB}}$ & $10.12 \pm 0.66^{\mathrm{cB}}$ & $11.82 \pm 0.77^{\mathrm{cA}}$ \\
\hline & 14 & $11.67 \pm 1.08^{\mathrm{aA}}$ & $11.26 \pm 0.89^{\mathrm{aA}}$ & $11.12 \pm 0.35^{\mathrm{dA}}$ \\
\hline
\end{tabular}

Mean \pm SD. $n=7-8$.

${ }^{\mathrm{a}-\mathrm{d}}$ Means in the same column with different letters are significantly differ $(p<0.05)$.

${ }^{\mathrm{A}-\mathrm{C}}$ Means in the same row with different letters are significantly differ $(p<0.05)$.

$L^{*}$, lightness; $a^{*}$, redness; $b^{*}$, yellowness. a, b, c, d: storage effects. A, B, C: procyanidin effects. 
al., 2005).

The value of $\mathrm{a}^{*}$ did not change in the control during storage, but the $\mathrm{a}^{*}$ values of the $0.1 \%$ procyanidin-treated samples increased gradually $(p<0.05)$ relative to the control at $10 \mathrm{~d}$. Procyanidin treatment $(0.3 \%)$ also increased $a^{*}$ value during storage. The values of $b^{*}$ also did not change significantly in the control during storage, but the $\mathrm{b}^{*}$ values were significantly greater $(p<0.05)$ in the samples treated with $0.3 \%$ procyanidin compared to and $0.1 \%$ procyanidin, except 10 and $14 \mathrm{~d}$.

Overall, the various procyanidin treatments and chilled storage times affected the color parameters of the pork patties. These results indicated that redness and yellowness were mainly different after procyanidin addition. Green tea and oregano extracts were previously shown to affect pork patty and beef color (Camo et al., 2011; Jo et al., 2003). Meat color alters by antioxidant activity or own color of procyanidin. The increased color itself can result from color introduced by the procyanidin (Carpenter et al., 2007). Our results are similar to those of previous studies (Millar et al., 2000; Nam and Ahn, 2002). The addition of procyanidin to meat patties is potentially useful for prolonging the shelf life of meat products by preserving the red color, and consumer demand for acceptable meat color. Meat color in particular is a major factor in consumer purchasing decisions because it is assumed to be an indicator of meat quality and freshness (Brewer et al., 2002; Killinge et al., 2004). Both of these characteristics have a major impact on consumer expectations of satisfaction (Robbins et al., 2003).

\section{pH values}

The $\mathrm{pH}$ values were measured with procyanidin-treated pork patties (Table 2). The $\mathrm{pH}$ value was not consistent change during all storage day. However, $0.3 \%$ procyanidin treatment was lower than those of control and $0.1 \%$ treatment during all storage time.

Changes of $\mathrm{pH}$ values on meat patties can affect the water-holding capacity and meat qualities (Parlak et al., 2011). The $\mathrm{pH}$ values of meat products (Banerjee et al., 2012) and turkey thigh meat (Du and Ahn, 2002) were reported to be decreased by broccoli powder as phenolic compounds. Broccoli had the highest phenolic amount compared to other vegetables such as, carrot, spinach, or onion (Chu et al., 2002). Overall, the $\mathrm{pH}$ values of the pork patties in this study were partly influenced by the procyanidin concentration.

\section{Volatile basic nitrogen (VBN) values}

The VBN values of pork patties after procyanidin addition are summarized in Table 3. The VBN values were not significantly different with procyanidin addition compared to the control except $0,7,10$, and $14 \mathrm{~d}$. The VBN values of the procyanidin-treated pork patties increased significantly $(p<0.05)$ during storage.

In this study, lower VBN values were associated with decreased protein breakdown caused by procyanidin, and the decrease in the VBN values of the pork patties during storage was caused by a reduction in the initial levels of common spoilage bacteria. Changes in VBN values are attributable to protein breakdown under aerobic (Fraqueza et al., 2008) or modified atmosphere (Ahn et al., 2000; Jay, 1992) package conditions and by the amino acid decarboxylase activity of microorganisms during storage (Han et al., 2006). Procyanidin exhibited a significant effect on the VBN content of the meat patties during storage. The VBN content in the meat patties treated with $0.3 \%$ procyanidin was lower than that of the patties treated with $0.01 \%$ procyanidin or the control patties. These results were similar to those for the changes in TBARS and the TBC in the pork patties described below. Meat quality such as, flavor, drip loss, hole water, color change,

Table 2. Effect of procyanidin on the $\mathrm{pH}$ values of pork patty during storage

\begin{tabular}{cccc}
\hline \hline Storage time $(\mathrm{d})$ & \multicolumn{3}{c}{ Procyanidin (\%) } \\
\cline { 2 - 4 } & 0 & $6.16 \pm 0.02^{\mathrm{bA}}$ & 0.3 \\
1 & $6.14 \pm 0.02^{\mathrm{bcA}}$ & $6.31 \pm 0.02^{\mathrm{aB}}$ & $5.93 \pm 0.03^{\mathrm{cB}}$ \\
3 & $6.37 \pm 0.03^{\mathrm{aA}}$ & $6.20 \pm 0.01^{\mathrm{bA}}$ & $6.06 \pm 0.02^{\mathrm{aC}}$ \\
7 & $6.20 \pm 0.01^{\mathrm{bA}}$ & $6.17 \pm 0.02^{\mathrm{bA}}$ & $6.00 \pm 0.02^{\mathrm{bB}}$ \\
10 & $6.16 \pm 0.01^{\mathrm{bcA}}$ & $6.07 \pm 0.12^{\mathrm{cAB}}$ & $6.06 \pm 0.02^{\mathrm{aB}}$ \\
14 & $6.20 \pm 0.14^{\mathrm{bA}}$ & $6.06 \pm 0.09^{\mathrm{cAB}}$ & $5.98 \pm 0.03^{\mathrm{bB}}$ \\
\hline
\end{tabular}

Mean \pm SD. $n=7-8$.

${ }^{\mathrm{a}-\mathrm{c}}$ Means in the same column with different letters are significantly differ $(p<0.05)$.

${ }^{\mathrm{A}-\mathrm{C}}$ Means in the same row with different letters are significantly differ $(p<0.05)$.

a, b, c: storage effects. A, B, C: procyanidin effects. 
Table 3. Effect of procyanidin on the volatile basic nitrogen (VBN) values of pork patties during storage

\begin{tabular}{cccc}
\hline \hline Storage time $(d)$ & 0 & Procyanidin (\%) & 0.3 \\
\cline { 2 - 4 } & $14.83 \pm 1.02^{\mathrm{eAB}}$ & 0.1 & $15.79 \pm 0.87^{\mathrm{cA}}$ \\
1 & $16.61 \pm 0.49^{\mathrm{d}}$ & $14.50 \pm 0.77^{\mathrm{dB}}$ & $16.93 \pm 0.36^{\mathrm{b}}$ \\
3 & $17.30 \pm 0.48^{\mathrm{c}}$ & $16.98 \pm 0.54^{\mathrm{c}}$ & $16.93 \pm 0.96^{\mathrm{b}}$ \\
7 & $18.07 \pm 0.28^{\mathrm{bA}}$ & $17.07 \pm 0.83^{\mathrm{c}}$ & $17.25 \pm 0.81^{\mathrm{bB}}$ \\
10 & $19.45 \pm 0.50^{\mathrm{aA}}$ & $19.08 \pm 0.73^{\mathrm{abA}}$ & $17.43 \pm 0.42^{\mathrm{bB}}$ \\
14 & $19.81 \pm 0.32^{\mathrm{aA}}$ & $19.40 \pm 0.41^{\mathrm{aA}}$ & $18.62 \pm 0.27^{\mathrm{aB}}$ \\
\hline
\end{tabular}

Mean \pm SD. $n=7-8$.

${ }^{a-c}$ Means in the same column with different letters are significantly differ $(p<0.05)$.

${ }^{\mathrm{A}-\mathrm{C}}$ Means in the same row with different letters are significantly differ $(p<0.05)$

a, b, c: storage effects. A, B, C: procyanidin effects.

or texture affected in meat by lipid oxidation (Weber and Antipatis, 2001) Thus, our findings suggest that pork patty shelf life can be improved slightly by the addition of $0.3 \%$ procyanidin.

\section{TBARS values}

The changes in TBARS values during storage of pork meat patties treated with procyanidin are summarized in Table 4 . The TBARS values of the pork patties increased significantly $(p<0.05)$ during storage. Especially, The TBARS values of the procyanidin-treated samples were significantly lower $(p<0.01)$ than those of the control samples at all storage days. Overall, the lowest TBARS values were produced by the highest procyanidin concentration, and TBARS values were significantly lower $(p<$ 0.05 ) in the procyanidin-treated pork patties than in the control.

Previous studies showed that the addition of 5,10 , or $15 \%$ tomato paste to pork patties resulted in significantly lower $(p<0.05)$ TBARS values compared to controls due to the antioxidative activity of lycopene present in the tomato paste (Kim et al., 2013). The TBARS values of these pork patties increased significantly $(p<0.05)$ during storage. These results were similar to those of beef meat and meat products treated with different tomato paste and spice extracts (Radha Krishnan et al., 2014; Valenzuela et al., 2014). Oxidative changes serve as an indicator of the degree of fresh meat product preservation, and the concentrations of grape antioxidants used in this study were sufficient to maintain the oxidative stability of the meat patties through the control of lipid oxidation. In general, the effect of lipid oxidation varies considerably depending on a complex interaction between various factors including the type and concentration of active compound(s) and the nature of the food system (Pandey and Rizvi, 2009).

\section{Microbiological analysis}

Changes in the aerobic bacteria population during storage of pork patties treated with procyanidin are summarized in Table 5. No significant difference was observed among treatments and storage times of 0,1 , and $3 \mathrm{~d}$. After $7 \mathrm{~d}$ of storage, the TBC values of the control and the 0.1 and $0.3 \%$ procyanidin-treated pork patties increased sig-

Table 4. Effect of procyanidin on the 2-thiobarbituric acid reactive substances (TBARS) values (mg malondialdehyde kg patty) of pork patties during storage

\begin{tabular}{cccc}
\hline \hline Storage time $(\mathrm{d})$ & \multicolumn{3}{c}{ Procyanidin (\%) } \\
\cline { 2 - 4 } & 0 & $0.02 \pm 0.01^{\mathrm{bB}}$ & 0.3 \\
1 & $0.13 \pm 0.07^{\mathrm{cA}}$ & $0.02 \pm 0.00^{\mathrm{bB}}$ & $0.03 \pm 0.00^{\mathrm{cB}}$ \\
3 & $0.27 \pm 0.18^{\mathrm{cA}}$ & $0.03 \pm 0.00^{\mathrm{bB}}$ & $0.04 \pm 0.01^{\mathrm{bB}}$ \\
7 & $0.57 \pm 0.28^{\mathrm{bA}}$ & $0.04 \pm 0.01^{\mathrm{bB}}$ & $0.04 \pm 0.00^{\mathrm{bB}}$ \\
10 & $0.89 \pm 0.11^{\mathrm{aA}}$ & $0.12 \pm 0.03^{\mathrm{aB}}$ & $0.04 \pm 0.01^{\mathrm{bB}}$ \\
14 & $0.90 \pm 0.02^{\mathrm{aA}}$ & $0.13 \pm 0.02^{\mathrm{aB}}$ & $0.01^{\mathrm{aC}}$ \\
\hline
\end{tabular}

\footnotetext{
Mean \pm SD. $n=7-8$.
}

${ }^{\mathrm{a}-\mathrm{c}}$ Means in the same column with different letters are significantly differ $(p<0.05)$.

${ }^{\mathrm{A}-\mathrm{C}}$ Means in the same row with different letters are significantly differ $(p<0.05)$.

a, b, c: storage effects. A, B, C: procyanidin effects. 
Table 5. Effect of procyanidin on the population of aerobic bacteria (colony forming units per gram) of pork patties during storage

\begin{tabular}{cccc}
\hline \hline Storage time $(\mathrm{d})$ & \multicolumn{3}{c}{ Procyanidin (\%) } \\
\cline { 2 - 4 } & 0 & 0.1 & 0.3 \\
\hline 0 & $0.93 \pm 0.24^{\mathrm{c}}$ & $0.55 \pm 0.38^{\mathrm{c}}$ & $0.58 \pm 0.39^{\mathrm{b}}$ \\
3 & $1.10 \pm 0.53^{\mathrm{cA}}$ & $0.50 \pm 0.51^{\mathrm{cB}}$ & $0.92 \pm 0.26^{\mathrm{bAB}}$ \\
7 & $0.65 \pm 0.79^{\mathrm{c}}$ & $0.44 \pm 0.68^{\mathrm{c}}$ & $0.65 \pm 0.78^{\mathrm{b}}$ \\
10 & $2.26 \pm 0.28^{\mathrm{bA}}$ & $1.89 \pm 0.75^{\mathrm{bAB}}$ & $0.86 \pm 1.23^{\mathrm{bB}}$ \\
14 & $3.06 \pm 0.49^{\mathrm{aA}}$ & $2.99 \pm 0.36^{\mathrm{aA}}$ & $1.19 \pm 0.34^{\mathrm{abB}}$ \\
\hline
\end{tabular}

Mean \pm SD. $n=7-8$.

${ }^{\mathrm{a}-\mathrm{c}}$ Means in the same column with different letters are significantly differ $(p<0.05)$.

${ }^{A-C}$ Means in the same row with different letters are significantly differ $(p<0.05)$.

a, b, c: storage effects. A, B, C: procyanidin effects.

nificantly $(p<0.05)$ relative to the initial TBC, but the TBC values of the procyanidin-treated patties were significantly lower $(p<0.05)$ than those of the control.

These results were similar to antimicrobial effects described previously (Calvo et al., 2008; Matsumoto et al., 2013). The low bacterial counts of the procyanidin-treated patties appeared to result from the content of antimicrobials such as phenolic compounds. Phenolics were previously shown to be among the most important compounds with activity against bacteria (Radha Krishnan et al., 2014; Widsten et al., 2014). Procyanidin can be used as an antibacterial agent to prevent the deterioration of pork meat patties caused by microbial contamination. E. coli was not detected in the procyanidin-treated samples and control during storage in this study (data not shown). Our findings suggest that food deterioration might not occur in meat processed using procyanidin.

\section{Conclusion}

Consumers increasingly demand healthier meat products, preferably free of artificial additives when possible. Procyanidin-treated samples exhibited significantly higher $(p<0.05)$ redness and yellowness values and lower $(p<0.05)$ VBN, TBARS, and TBC values compared to control samples during storage. The addition of procyanidin to pork patties had significant effects on color, $\mathrm{pH}, \mathrm{VBN}$, lipid oxidation, and microbial populations in a time- and dosedependent manner. Therefore, procyanidin could be used as a natural antioxidant and antimicrobiological safety agent during the storage of meat and meat products. Our findings suggest that procyanidin can be used to improve the shelf life of pork patties and meat products, and improve food safety and freshness for consumers.

\section{Acknowledgements}

This work was carried out with the support of "Cooperative Research Program for Agriculture Science \& Technology Development (Project title: Screening of starter cultures for Korean fermented sausage, Project No. PJ010 8602015)" and 2015 Postdoctoral Fellowship Program of National Institute of Animal Science, Rural Development Administration, Republic of Korea.

\section{References}

1. Ahn, D. U., Jo, C., Du, M., Olson, D. G., and Nam, K. C. (2000) Quality characteristics of pork patties irradiated and stored in different packaging and storage conditions. Meat Sci. 56, 203-209.

2. Ahn, J., Grün, I. U., and Mustapha, A. (2007) Effects of plant extracts on microbial growth, color change, and lipid oxidation in cooked beef. Food Microbiol. 24, 7-14.

3. Banerjee, R., Verma, A. K., Das, A. K., Rajkumar, V., Shewalkar, A. A., and Narkhede, H. P. (2012) Antioxidant effects of broccoli powder extract in goat meat nuggets. Meat Sci. 91, 179-184.

4. Bañón, S., Díaz, P., Rodríguez, M., Garrido, M. D., and Price, A. (2007) Ascorbate, green tea and grape seed extracts increase the shelf life of low sulphite beef patties. Meat Sci. 77, 626633.

5. Barbosa-Pereira, L., Bilbao, A., Vilches, P., Angulo, I., LLuis, J., Fité, B., Paseiro-Losada, P., and Cruz, J. M. (2015) Brewery waste as a potential source of phenolic compounds: optimisation of the extraction process and evaluation of antioxidant and antimicrobial activities. Food Chem. 145, 191-197.

6. Bekhit, A. D., Geesink, G. H., Ilian, M. A., Morton, J. D., Sedcole, R., and Bickerstaffe, R. (2003) Particulate metmyoglobin reducing activity and its relationship with meat color. J. Agric. Food Chem. 51, 6026-6035.

7. Brewer, M. S., Jensen, J., Sosnicki, A. A., Fields, B., Wilson, E., and McKeith, F. K. (2002) The effect of pig genetics on 
palatability, color and physical characteristics of fresh pork loin chops. Meat Sci. 61, 249-256.

8. Calvo, M. M., Garciia, M. L., and Selgas, D. M. (2008) Dry fermented sausages enriched with lycopene from tomato peel. Meat Sci. 80,167-172.

9. Camo, J., Lorés, A., Djenane, D., Beltrán, J. A., and Roncalés, P. (2011) Display life of beef packaged with an antioxidant active film as a function of the concentration of oregano extract. Meat Sci. 88, 174-178.

10. Carpenter, R., O'Grady, M. N., O'Callaghan, Y. C., O'Brien, N. M., and Kerry, J. P. (2007) Evaluation of the antioxidant potential of grape seed and bearberry extracts in raw and cooked pork. Meat Sci. 76, 604-610.

11. Chu, Y. F., Sun, J., Wu, X., and Liu, R. H. (2002) Antioxidant and antiproliferative activities of common vegetables. J. Agric. Food Chem. 50, 6910-6916.

12. Conway, E. J. (1950) Microdiffusion and volumetric error 3rd ed. Crosby Lockwood and Son Ltd, London, UK, pp. 87-107.

13. Dave, D. and Ghaly, A. E. (2011) Meat spoilage mechanisms and preservation techniques: A critical review. Am. J. Agric. Biol. Sci. 6, 486-510.

14. Du, M. and Ahn, D. U. (2002) Effect of antioxidants on the quality of irradiated sausages prepared with turkey thigh meat. Poultry Sci. 81, 1251-1256.

15. Fraqueza, M. J., Ferreira, M. C., and Barreto, A. S. (2008) Spoilage of light (PSE-like) and dark turkey meat under aerobic or modified atmosphere package: Microbial indicators and their relationship with total volatile basic nitrogen. $B r$. Poultry Sci. 49, 12-20.

16. Han, K. H., Choi, I. S., and Lee, C. H. (2006) The physicochemical and storage characteristics of sausage added mugwort powder. Korean J. Food Sci. An. 26, 356-361.

17. Hemilä, H., Kaprio, J., Albanes, D., and Virtamo, J. (2006) Physical activity and the risk of pneumonia in male smokers administered vitamin E and beta-carotene. Int. J. Sports Med. 27, 336-341.

18. Hu, M., McClements, D. J., and Decker, E. A. (2004) Antioxidant activity of a proanthocyanidin-rich extract from grape seed in whey protein isolate stabilized algae oil-in-water emulsions. J. Agric. Food Chem. 52, 5272-5276.

19. Jay, J. M. (1992) Modern Food Microbiology, Fourth Edition. Van Nostrand Reinhold, New York, pp. 701.

20. Jo, C., Son, J. H., Son, C. B., and Byun, M. W. (2003) Functional properties of raw and cooked pork patties with added irradiated, freeze-dried green tea leaf extract powder during storage at $4^{\circ}$ C. Meat Sci. 64, 13-17.

21. Karre, L., Lopez, K., and Getty, K. J. (2013) Natural antioxidants in meat and poultry products. Meat Sci. 94, 220-227.

22. Killinger, K. M., Calkins, C. R., Umberger, W. J., Feuz, D. M., and Eskridge, K. M. (2004) Consumer visual preference and value for beef steaks differing in marbling level and color. $J$. Anim. Sci. 82, 3288-3293.

23. Kim, I. S., Jin, S. K., Yang, M. R., Chu, G. M., Park, J. H., Rashid, R. H., Kim, J. Y., and Kang, S. N. (2013) Efficacy of tomato powder as antioxidant in cooked pork patties. AsianAustralas. J. Anim. Sci. 26, 1339-1346.
24. Loizzo, M. R., Tundis, R., Menichini, F., and Duthie, G. (2015) Anti-rancidity effect of essential oils, application in the lipid stability of cooked turkey meat patties and potential implications for health. Int. J. Food Sci. Nutr. 66, 50-57.

25. Matsumoto, M., Hiramatsu, R., Yamada, K., Suzuki, M., Miwa, Y., Yabutani, M., Nagai, Y., Tsuchiya, M., Noda, M., Nagata, A., Kawakami, K., Shima, T., Tatsumi, N., and Minagawa, H. (2013) Phenotypic and genetic analyses of Campylobacter jejuni Lior serotype 76 isolated from chicken meat and clinical specimens. Jpn. J. Infect. Dis. 66, 72-75.

26. Millar, S. J., Moss, B. W., and Stevenson, M. H. (2000) The effect of ionising radiation on the colour of beef, pork and lamb. Meat Sci. 55, 349-360.

27. Mitropoulou, G., Fitsiou, E., Stavropoulou, E., Papavassilopoulou, E., Vamvakias, M., Pappa, A., Oreopoulou, A., and Kourkoutas, Y. (2015) Composition, antimicrobial, antioxidant, and antiproliferative activity of Origanum dictamnus (dittany) essential oil. Microb. Ecol. Health Dis. 26, 26543.

28. Mitsumoto, M., O'Grady, M. N., Kerry, J. P., and Joe Buckley, D. (2005) Addition of tea catechins and vitamin C on sensory evaluation, colour and lipid stability during chilled storage in cooked or raw beef and chicken patties. Meat Sci. 69, 773-779.

29. Movileanu, I., Máryuri, T., Brian, H., Rhonda, K. M., and Jimmy, T. K. (2013) Comparison of Dried Plum Puree, Rosemary Extract, and BHA/BHT as Antioxidants in Irradiated Ground Beef Patties. Int. J. Food Sci. 2013, 7p.

30. Nam, K. C. and Ahn, D. U. (2002) Carbon monoxide-heme pigment is responsible for the pink color in irradiated raw turkey breast meat. Meat Sci. 60, 25-33.

31. Negro, C., Tommasi, L., and Miceli, A. (2003) Phenolic compounds and antioxidant activity from red grape marc extracts. Bioresour. Technol. 87, 41-44.

32. Nissen, L. R., Byrne, D. V., Bertelsen, G., and Skibsted, L. H. (2004) The antioxidative activity of plant extracts in cooked pork patties as evaluated by descriptive sensory profiling and chemical analysis. Meat Sci. 68, 485-495.

33. Pandey, K. B. and Rizvi, S. I. (2009) Plant polyphenols as dietary antioxidants in human health and disease. Oxid. Med. Cell. Longev. 2, 270-278.

34. Parlak, O., Zorba, O., and Kurt, S. (2011) Modelling with response surface methodology of the effects of egg yolk, egg white, and sodium carbonate on some of the physical-chemical and sensory properties of beef patties. Int. J. Food Eng. 51, 780-784.

35. Pazos, M., Gallardo, J. M., Torres, J. L., and Medina, I. (2005) Activity of grape phenols as inhibitors of the oxidation of fish lipids and frozen fish muscle. Food Chem. 92, 547-557.

36. Radha Krishnan, K., Babuskin, S., Azhagu Saravana Babu, P., Sasikala, M., Sabina, K., Archana, G., Sivarajan, M., and Sukumar, M. (2014) Antimicrobial and antioxidant effects of spice extracts on the shelf life extension of raw chicken meat. Int. J. Food Microbiol. 171, 32-40.

37. Robbins, K., Jensen, J., Ryan, K. J., Homco-Ryan, C., McKeith, F. K., and Brewer, M. S. (2003) Consumer attitudes towards beef and acceptability of enhanced beef. Meat Sci. 65, 
721-729.

38. Rojas, M. C. and Brewer, M. S. (2007) Effect of natural antioxidants on oxidative stability of cooked, refrigerated beef and pork. J. Food Sci. 72, S282-S288.

39. Sasse, A., Colindres, P., and Brewer, M. S. (2009) Effect of natural and synthetic antioxidants on the oxidative stability of cooked, frozen pork patties. J. Food Sci. 74, S30-S35.

40. Shah, M. A., Bosco, S. J., and Mir, S. A. (2014) Plant extracts as natural antioxidants in meat and meat products. Meat Sci. 98, 21-33.

41. Shi, J., Yu, J., Pohorly, J. E., and Kakuda, Y. (2003) Polyphenolics in grape seeds-biochemistry and functionality. $\mathrm{J}$. Med. Food 6, 291-299.

42. Sivarooban, T., Hettiarachchy, N. S., and Johnson, M. G. (2007) Inhibition of Listeria monocytogenes using nisin with grape seed extract on turkey frankfurters stored at 4 and 10 degrees C. J. Food Prot. 70, 1017-1020.

43. Valenzuela Melendres, M., Camou, J. P., Torrentera Olivera, N. G., Alvarez Almora, E., González Mendoza, D., Avendaño
Reyes, L., and González Ríos, H. (2014) Response surface methodology for predicting quality characteristics of beef patties added with flaxseed and tomato paste. Meat Sci. 97, 5461.

44. Weber, G. M. and Antipatis, C. (2001) Pork meat quality and dietary vitamin E. Second International Virtual Conference on Pork Quality.

45. Widsten, P., Cruz, C. D., Fletcher, G. C., Pajak, M. A., and McGhie, T. K. (2014) Tannins and extracts of fruit byproducts: antibacterial activity against foodborne bacteria and antioxidant capacity. J. Agric. Food Chem. 62, 11146-11156.

46. Witte, V. C., Krause, G. F., and Bailey, M. E. (1970) A new extraction method for determining 2-thiobarbituric acid values for pork and beef during storage. J. Food Sci. 35, 585592.

47. Wood, J. E., Senthilmohana, S. T., and Peskinb, A. V. (2002) Antioxidant activity of procyanidin-containing plant extracts at different pHs. Food Chem. 77, 155-161. 